\title{
PENGARUH PENDEKATAN OPEN ENDED MENGGUNAKAN MODEL PEMBELAJARAN STAD TERHADAP HASIL BELAJAR SISWA PADA MATERI HUKUM DASAR KIMIA KELAS X DI SMAN 01 WANARAYA
}

\author{
The Effect of Open-Ended Approach Using STAD Learning Model on \\ Student's Learning Outcomes on Basic Chemical Law Materials in Class X of \\ SMAN 01 WANARAYA \\ Sri Lestari Ani, Novi Rahmawanti, Herlina Apriani \\ Program Studi Pendidikan Kimia Fakultas Keguruan dan Ilmu Pendidikan \\ Universitas Islam Kalimantan (Uniska) Muhammad Arsyad Al Banjari, Banjarmasin \\ *e-mail:Srilestariani96@gmail.com
}

\begin{abstract}
Abstrak. Penelitian ini bertujuan untuk mengetahui pengaruh pendekatan Open Ended menggunakan model pembelajaran STAD terhadap hasil belajar siswa pada materi hukum dasar kimia kelas X di SMAN 1 Wanaraya. Penelitian ini dilakukan di SMAN 01 Wanaraya dengan menggunakan dua kelas yaitu kelas eksperimen dan kelas kontrol. Instrumen yan digunakan berupa tes objektif ranah kognitif dengan soal pilihan ganda, penelitian ini menggunakan quasi eksperiment atau eksperimen semu, sedangkan sampel penelitian ini yaitu X IPA A dan X IPA B berjumlah 65 siswa. Hasil uji kelayakan pendekatan Open Ended menggunakan model pembelajaran STAD dilakukan oleh tiga validator untuk materi dan soal tes. Hasil penelitian menunjukan nilai sig sebesar 0.02 sehingga kesimpulan penelitian adalah terdapat pengaruh pendekatan Open Ended dengan model pembelajaran STAD terhadap hasil belajar siswa pada materi hukum dasar kimia di SMAN 01 Wanaraya.
\end{abstract}

Kata Kunci: Hukum dasar kimia, pendekatan Open Ended, STAD (student teams achievement division), hasil belajar

\begin{abstract}
This study aimed to determine the effect of Open-Ended approach using STAD learning model on student learning outcomes in the basic chemistry law material at class X SMAN 1 Wanaraya. This research was conducted at SMAN 01 Wanaraya using two classes, namely the experimental class and the control class. The instrument used in the form of objective tests of cognitive domains with multiple choice questions, this study used quasi experimental design, while the samples of this study were X IPA A and X IPA B totaling 65 students. The results of the feasibility test for the Open-Ended approach using the STAD learning model were obtained from three validators for the material and test questions. The research result obtained was a sig. value of 0.02 so the conclution of this research there was effect of Open-Ended approach using STAD learning model on student's learning outcomes in the basic laws of chemistry material at class X SMAN 1 Wanaraya.
\end{abstract}

Keywords: Basic laws of chemistry, Open Ended approach, STAD (student teams achievement division), learning outcomes 


\section{PENDAHULUAN}

Salah satu upaya untuk menciptakan agar pendidikan berkembang dan berkualitas dengan cara memberikan pengajaran yang tidak membosankan bagi siswa dan perlu adanya perbaikan dalam proses pembelajaran terutama pembelajaran kimia. Pembelajaran kimia juga banyak memerlukan variasi dalam proses belajar mengajar baik dalam model pembelajaran, media, maupun sumber belajar. Agar pembelajaran dapat berjalan dengan menarik diperlukan guru yang kreatif dan inovatif untuk dapat memiliki stategi pembelajaran yang tepat. Keberhasilan dalam proses belajar tidak lepas dari hasil metode pembelajaran, sedangkan keberhasilan dalam pembelajaran juga tergantung dari keberhasilan siswa dalam mengikuti proses belajar (Achmad,2004). Pada proses pembelajaran yang terlalu monoton pada ceramah di kelas dan kurang menerapkan proses pembelajaran maka menyebabkan pelajaran kimia kurang disenangi dan cenderung dipandang sulit oleh siswa (Khan dan arshad, 2011). Penerapan model pembelajaran yang tepat diharapkan dapat menciptakan suasana peserta didik aktif sehingga terjadi interaksi diantar peserta didik dalam proses pembelajaran (Ana dkk, 2019).

Mata pelajaran kimia khususnya di SMA sering dijadikan materi yang susah dan dianggap siswa sesuatu yang menakutkan. Hal ini membuat siswa enggan untuk menyatukan pikiran mereka dengan pelajaran kimia dan secara tidak langsung cara berpikir siswa terutama untuk mata pelajaran kimia sangat sulit untuk dimunculkan. Banyak sekolah yang menggunakan sistem lama, yaitu pembelajaran berpusat pada guru untuk mencapai tujuan pembelajaran yang efektif dan efisien (Djamarah \& Zain , 2010). Namun disini penulis menerapkan pendekatan Open Ended. Pendekatan Open Ended menjanjikan suatu kesempatan kepada siswa untuk menginvestigasi berbagai strategi dan cara yang diyakini sesuai dengan kemampuan mengolaborasi permasalahan (Martunis, 2014). Pendekatan Open Ended merupakan pendekatan pembelajaran yang lebih menekankan siswa untuk sampai pada jawaban dari pada kebenarannya atau ketepatan jawaban semata, siswa dihadapkan pada suatu masalah yang memiliki ragam jawaban benar lebih dari satu. Untuk lebih menunjang keberhasilan pendekatan Open Ended penulis menggunakan Pembelajaran kooperatif tipe STAD.

Menurut Trianto (2011), pembelajaran kooperatif tipe STAD merupakan salah satu model pembelajaran kooperatif yang menggunakan kelompok-kelompok kecil dengan jumlah anggota tiap kelompok 4-5 orang siswa secara heterogen. terdapat tiga konsep utama yang dapat meningkatkan hasil belajar dan mendorong siswa untuk aktif dalam pelajaran, 3 konsep utama dalam STAD yaitu penghargaan kelompok, tanggung jawab individu dan peluang yang sama untuk sukses. Hal ini dikarenakan keberhasilan dan pencapaian tujuan kelompok pada pembelajaran kooperatif tipe STAD bergantung pada semua anggota kelompok. Dengan ini diharapkan kedepannya akan mencapai tujuan maksimal terhadap pendekatan Open Ended menggunakan model pembelajaran STAD yang akan meningkatkan hasil belajar siswa pada materi Hukum Dasar Kimia yang dianggap sulit dan dapat membuka pikiran siswa materi Hukum Dasar Kimia menjadi menyenangkan.

\section{METODE PENELITIAN}

Penelitian ini termasuk penelitian eksperimen semu atau quasi eksperimen, Desain penelitian yang digunakan adalah non equaivalence control grup design. 
Penelitian dilaksanakan di SMAN 1 Wanaraya pada bulan april 2019 sampai dengan selesai. Populasi dan sampel dalam penelitian ini menggunakan cluster sampling agar setiap populasi memiliki kesempatan yang sama untuk menjadi sampel dalam penelitian. Sampel dalam penelitian ini terdiri dua kelas yaitu kelas X IPA A dan X IPA C di SMAN 01 Wanaraya, dimana kelas $\mathrm{X}$ ipa A sebagai kelas eksperimennya dan kelas $\mathrm{X}$ IPA C sebai kelas kontrol. Teknik pengumpulan data menggunakan soal pilihan ganda dengan jumlah soal 20 soal. Hasil data yang diperoleh dianalisis dengan menggunakan Uji T Independen untuk mengetahui perbedaan menggunakan pendekatan Open Ended dengan STAD pada kelas eksperimen dan kelas kontrol menggunakan model pembelajaran STAD.

\section{HASIL DAN PEMBAHASAN}

Berdasarkan data hasil penelitian hasil belajar siswa sebelum dan sesudah belajar tentang materi hukum dasar kimia, dilihat pada tabel 1 nilai pre-test siswa lebih rendah bila di bandingkan dengan nilai postest.

Tabel 1. Hasil Belajar Siswa

\begin{tabular}{lcc}
\hline Komponen & Kelas Kontrol & Kelas Eksperimen \\
\hline Pretest & 54.06 & 56,21 \\
Pos-test & 64,53 & 70.55 \\
Jumlah siawa & 32 & 33 \\
\hline
\end{tabular}

Dari analisis data menggunakan uji normalitas dapat dilihat pada tabel 2 . Setelah dilakukan uji normalitas data bersifat normal.

Tabel 2. Uji Normalitas

\begin{tabular}{lccc}
\hline Kelas & Sig & A & Keterangan \\
\hline Kontrol & 0.19 & 0.05 & Normal \\
Eksperimen & 0.06 & 0.05 & Normal \\
\hline
\end{tabular}

Uji homogenitas dapat dilihat pada tabel 3. Setelah dilakukan uji homogenitas data bersifat homogen.

Tabel 3. Uji Homogenitas

\begin{tabular}{lccc}
\hline Kelas & Sig & A & Keterangan \\
\hline Kontrol & 0.98 & 0.05 & Homogen \\
Eksperimen & 0.98 & 0.05 & Homogen \\
\hline
\end{tabular}

Kemudian karena uji normalitas dan homogenitas data terpenuhi maka dilakukan uji $\mathrm{T}$ independen yang dapatdilihat pada tabel 4. 
Tabel 4. Uji T Independen

\begin{tabular}{lccc}
\hline Kelas & Sig & A & Keterangan \\
\hline Kotrol & 0.02 & 0.05 & Terdapat pengaruh \\
Eksperimen & 0.02 & 0.05 & Terdapat pengaruh \\
\hline
\end{tabular}

Pada penelitian ini, Instrumen yang digunakan dalam penelitian harus melalui uji kelayakan instrumen terlebih dahulu, instrumen yang digunakan dalam penelitian ini adalah soal tes.Hasil validasi butir soal menggunakan aplikasi SPSS V.16 dari 25 soal terdapat 20 soal yang valid dan 5 soal yang tidak valid seperti korelasi pada uji validitas menggunakan korelasi item total yang di kutip dari Rochaety (2007), jika sig $<0,05$ data dapat diterima, dan sig > 0,05 data tidak dapat diterima. Validasi dan soal tes dilakukan oleh tiga validator yakni dua orang guru dan satu dosen. Persentase perolehan skor yang didapatkan yakni $96,9 \%$ terdapat pada kriteria sangat tinggi. Uji reliabilitas dilakukan menggunakan aplikasi SPSS V.16 dimana diperoleh data hasil nilai Alpha nya 0.956 yang artinya butir instrument tersebut memiliki tingkat reliabilitas sangat tinggi. .

Dari uji taraf kesukaran menggunakan aplikasi anates versi 4 dengan memasukkan hasil data nilai siswa. Berdasarkan hasil pengujian instrumen menggunakan program Anates dari 20 soal didapat soal sangat mudah ada 4 soal dengan indeks $90 \%$ dan mudah ada 13 soal dengan indeks $85 \%$, sedangkan untuk soal sedang ada 1 soal dengan indeks $60 \%$, soal sukar ada 1 soal dengan indeks $25 \%$, dan soal sangat sukar ada 1 soal dengan indeks $15 \%$. Pada uji daya pembeda menggunakan aplikasi anatest versi 4 didapatkan hasil uji daya pembeda soal dari 20 butir soal ada 2 butir soal yang kriteria jelek, ada 12 butir soal yang kriteria cukup ,ada 4 butir soal yang kriteria baik dan 2 butir soal yang kriteria baik sekali.

Data hasil uji normalitas pada kelas kontrol dan kelas ekperimen baik menunjukan bahwa data tersebut berdistribusi normal. Hal tersebut berdasarkan hasil data menggunakan aplikasi SPSS V.16 yakni nilai sig kelas eksperimen pada sebesar 0,06 dan kelas kontrol 0.19 dimana nilai sig tersebut lebih besar dibandingkan nilai alpha yang artinya berdistribusi normal. Menurut Ghozali (2013) data disebut homogen apabila hasil uji homogenitas didapatkan sig > 0,05. Hasil data penelitian menggunakan aplikasi SPSS V.16 menunjukkn nilai sig pada 0.67 sehinga dapat dikatakan bahwa data homogen.

Pada hasil belajar siswa dilihat dari hasil pretest yang diberikan sebelum dilakukan pembelajaran dan post test yang diberikan pada akhir pertemuan. Tes berbentuk pilihan ganda yang berjumlah 20 soal yang setiap soal mempunyai bobot skor yang sama. Kondisi awal kemampuan berpikir kreatif siswa secara keseluruhan termasuk kedalam kategori rendah karena nilai rata-rata pada kelas eksperimen adalah 56,21 dan pada kelas kontrol adalah 54,06. Berdasarkan data di atas pada kelas eksperiment maupun kelas kontrol, terlihat bahwa nilai siswa masih kurang dalam menjawab soal pada indikator kemampuan hasil belajar siswa. Untuk kelas eksperimen diberi perlakuan menggunakan pendekatan Open Ended dengan model pembelajaran STAD, sedangkan untuk kelas kontrol diberi perlakuan hanya menggunakan model pembelajaran STAD saja, agar peneliti dapat melihat apakah terdapat pengaruh menggunakan pendekatan Open Ended. 
Berbeda halnya dengan kondisi akhir hasil belajar siswa yang termasuk dalam kategori tinggi yakni nilai rata-rata pada kelas eksperimen adalah 70,55 dan pada kelas kontrol adalah 64,53 terjadi peningkatan pada indikator yang dinilai dalam hasil belajar siswa. Berdasarkan gambar di atas, terlihat bahwa nilai siswa meningkat dalam hasil belajar siswa. Begitu juga dengan kelas kontrol, kondisi awal kemampuan hasil belajar siswa secara keseluruhan termasuk kedalam kategori rendah tetapi setelah di beri perlakuan nilai siswa meningkat.

Berdasarkan tabel hasil pretest dan post test siswa kelas eksperimen dan kontrol di atas, terlihat bahwa peningkatan hasil belajar siswa kelas eksperimen lebih tinggi dibandingkan dengan kelas kontrol. Hal ini dapat dibuktikan dengan perolehan nilai di atas pada kelas kontrol yaitu nilai minimum 20 dan nilai maksimum 80 dengan nilai rata-rata 64,53 sedangkan pada kelas eksperimen nilai minimum 60 dan nilai maksimum 85 dengan nilai rata-rata 70,55 Jadi, dapat disimpulkan peningkatan hasil belajar siswa dengan pendekatan Open-Ended menggunakan model pembelajaran STAD lebih tinggi dibandingkan hasil belajar siswa dengan hanya menggunakan model pembelajaran STAD saja.

Hasil belajar siswa yang diharapkan adalah siswa dapat menjawab soal-soal dengan cermat dan benar. Hasil tes ini bertujuan untuk mengetahui peningkatan hasil belajar siswa dan perbedaan hasil belajar siswa pada kedua kelas tersebut. Data yang diperoleh diolah dan dianalisis serta dilakukan pengujian hipotesis. Berdasarkan kriteria pengujian hipotesis I dengan menggunakan uji-t kelas eksperimen. Pada taraf signifikan $\alpha=0,05$. Rochaety (2007) yang menyatakan bahwa data diterima jika sig $<0,05$ dan data tidak diterima jika nilai sig $>0,05$. Hasil pengujian diperoleh $0,02<0,05$. Berdasarkan kriteria pengambilan keputusannya, $\mathrm{H}_{0}$ ditolak dan $\mathrm{H}_{1}$ diterima. Pada kelas eksperimen dan kontrol dengan taraf signifikan $\alpha=0,05$ kriteria pengujian, diperoleh taraf signifikan $0,02<0,05$. Berdasarkan kriteria pengujian jika nilai signifikan kurang dari 0,05 maka $\mathrm{H}_{0}$ ditolak dan $\mathrm{H}_{1}$ diterima. Dengan demikian, dapat disimpulkan bahwa terdapat peningkatan kemampuan berpikir kreatif siswa melalui penerapan pendekatan Open-Ended menggunakan model pembelajaran STAD pada materi hukum dasar kimia pada kelas eksperimen.

Adapun hasil belajar siswa sebelum diberikan perlakuan dengan menerapkan pendekatan Open-Ended menggunakan model pembelajaran STAD masih "rendah", namun setelah diberi perlakuan dengan menerapkan pendekatan Open-Ended dengan model pembelajaran STAD lebih tinggi di kategorikan "sedang". Dapat disimpulkan bahwa hasil belajar siswa yang belajar dengan pendekatan Open-Ended dengan model pembelajaran STAD lebih tinggi dari pada hasil belajar siswa yang belajar dengan menggunakan model pembelajaran STAD saja. Dalam pelaksanaannya siswa diminta untuk memecahkan masalah dengan membiarkan siswa mengembangkan cara berpikirnya dan menggunakan strategi penyelidikan masalah yang meyakinkan baginya. Pendekatan ini memberi keleluasaan kepada siswa untuk melakukan elaborasi lebih besar sehingga memungkinkan bertambahnya kemampuan berpikirnya dan meningkatnya hasil belajar siswa. Pendekatan Open-Ended memberikan banyak kesempatan kepada siswa untuk menggunakan berbagai kompetensi yang dimilikinya dalam memecahkan masalah. 


\section{SIMPULAN}

Berdasarkan hasil penelitian dan pembahasan dapat disimpulkan bahwa terdapat pengaruh pendekatan Open Ended menggunakan model pembelajaran STAD terhadap hasil belajar siswa pada materi Hukum Dasar Kimia di kelas X di SMAN 1 Wanaraya.

\section{DAFTAR RUJUKAN}

Achmad, M. (2004). Teori Belajar Dan Pembelajaran. Jakarta : KencanaPrenada Media Group.

Ana, S. L., Rahmawanti, N., Dony, N. (2019). Pengaruh Model Pembelajaran Kooperatif Tipe Bamboo Dancing Pada Materi Koloid Terhadap Hasil Belajar Siswa Kelas XI SMAN 1 Wanaraya. Dalton: Jurnal Pendidikan Kimia dan Ilmu Kimia, 2(2), 45-50.

Syaiful Bahri dan Aswan Zain. (2010). Strategi Belajar Mengajar. Jakarta: Rineka Cipta.

Ghozali, I. (2013). Aplikasi Analisis Multivariate dengan Program IBM SPSS 21 Update PLS Regresi. Semarang: Badan Penerbit Universitas Diponegoro.

Khan, G.N dan Arshad, A. (2012). Higher Secondary School Students' Attitude towards Chemistry. Journal of Asian Social Science, 8(6),165-169.

Martunis. (2014). Pembelajaran Open Ended Pada Luas Segitiga Siswa SMA Negeri 2 Indrajaya. Jurnal Sains Riset, 1(19), 13-21

Rochaety, E. (2007). Metodologi Penelitian Bisnis. Jakarta : Mitra Wacana Media.

Trianto. (2011). Model Model pembelajaran inovatif berorientasi Konstruktivistik. Jakarta: Prestasi Pustaka. 